\title{
PELAKSANAAN PENDIDIKAN AGAMA ISLAM SECARA FORMAL PADA MASYARAKAT NELAYAN TERPENCIL TANAH KUNING
}

\author{
Abdul Arif \\ Program Studi Matematika, Universitas Kaltara \\ Email: fmipaunikaltar@gmail.com. HP; 081254473789
}

\begin{abstract}
The concept of fostering fishing communities within the framework of a sustainable fisheries development perspective in Indonesia needs to be studied properly, precisely and touches on the targets to be achieved. This study aims to 1) Determine the character of the remote community of Tanah Kuning fishermen, 2) Systems and practices of the implementation of Islamic education, 3) Supporting and inhibiting factors in Islamic education, 4) Educational models that are appropriate to the characteristics of the remote fishing communities of Tanah Kuning. The results of this study include people with livelihoods as fishermen who are not willing to make changes unless someone starts, the education system has not been able to run in accordance with the existing objectives. The supporting and inhibiting factors produced were religious teachers who still received respect from the community and adequate school buildings, monotonous teachers, inadequate books, only one teacher, and community perceptions that considered education less important. The educational model used the Gagne model which creates external conditions in line with the internal conditions of student learning processes.
\end{abstract}

Keywors: Character, Supporting and Inhibiting Factors, Model.

\begin{abstract}
Abstrak
Konsep pembinaan masyarakat nelayan dalam kerangka perspektif pembangunan perikanan yang berkelanjutan di Indonesia perlu dikaji secara baik, tepat dan menyentuh sasaran yang ingin dicapai. Penelitian ini bertujuan 1) Mengetahui karakter masyarakat nelayan terpencil Tanah Kuning, 2) Sistem dan praktek pelaksanaan pendidikan Agama Islam, 3) Faktor pendukung dan penghambat dalam pendidikan Agama Islam, 4) Model pendidikan yang sesuai dengan karakteristik masyarakat nelayan terpencil Tanah Kuning. Hasil dari penelitian ini meliputi masyarakat dengan mata pencaharian sebagai nelayan yang tidak bersedia membuat perubahan kecuali ada yang memulai, sistem pendidikan belum dapat berjalan sesuai dengan tujuan yang ada. Adapun faktor pendukung dan penghambat yang dihasilkan adalah guru agama yang masih mendapat penghormatan dari masyarakat dan gedung sekolah yang cukup memadai, pengajar yang monoton, buku kurang memadai, guru yang hanya satu, dan persepsi masyarakat yang menganggap pendidikan kurang penting. Model pendidikan digunakan model Gagne yang menciptakan kondisi eksternal sejalan dengan kondisi internal proses belajar siswa.
\end{abstract}

Kata Kunci: Karakter, Faktor Pendukung dan Penghambat, Model 


\section{PENDAHULUAN}

Pendidikan Agama Islam mempunyai kedudukan dan peranan yang sangat penting didalam pembangunan bangsa. Dalam konteks pembangunan bangsa, pendidikan karakter merupakan usaha sadar dan terencana untuk mewujudkan suasana serta proses pemberdayaan potensi dan pembudayaan peserta didik guna membangun karakter pribadi atau kelompok yang bertujuan dapat memberikan kontribusi optimal dalam mewujudkan masyarakat sesuai Pancasila (Hamdani dan Saebani, 2013). Tujuan dari pendidikan karakter adalah mengajarkan nilai-nilai tradisional tertentu, nilai-nilai yang diterima secara luas sebagai landasan prilaku yang baik dan bertanggung jawab (Kementrian Pendidikan dan Kebudayaan RI, 2010). Oleh karena itu, dalam rangka pencapaian tujuan pendidikan maka perlu diusahakan agar pendidikan Agama Islam dapat dilaksanakan secara efektif dan efisien melalui perbaikan metode dan sistem, penyempurnaan materi dan sarana yang mencukupi.

Kehidupan keluarga nelayan menggunakan sistem gender yaitu sistem pembagian kerja secara seksual dalam masyarakat nelayan yang didasarkan pada persepsi kebudayaan yang ada. Dalam rumah tangga nelayan miskin mengambil peranan strategi untuk menjaga rumah tangganya (Kusnadi, 2010).

Masri (2017) dalam penelitiannya menemukan bahwa anak nelayan pesisir memerlukan pendekatan yang berbeda dengan pendidikan formal pada umumnya. Pola pendidikan yang sesuai dengan keperluan anak nelayan pesisir yang mengutamakan kepentingan pemenuhan hidup yang dapat meningkatkan kesejahteraan anak dan atau dapat meningkatkan pemenuhan kualitas pembelajaran anak sehingga diperlukan sebuah sistem pembelajaran yang sesuai dengan kondisi masyarakat pesisir. Materi pembelajaran kepada peserta didik, jadwal pembelajaran dan sistem pembelajaran. Dengan demikian bahwa pola pendidikan kecakapan hidup masyarakat pesisir dan model pendidikan dasar yang sesuai atau alternatif model pendidikan dasar perlu menjadi perhatian. Sehingga beralasan jika anak nelayan perlu dicarikan model pembelajaran yang sesuai dengan kondisi dan keperluan kehidupan mereka.

Hal yang sama terlihat pada hasil penelitian Marlin (2016) bahwa konstruksi sosial orang tua dalam keluarga nelayan di Desa Muarareja Kecamatan Tegal Barat Kota Tegal tentang pendidikan anak yang masih rendah, kurang perhatian orang tua terhadap pendidikan anak karena memandang bahwa pendidikan tidak penting. 
Pola asuh anak keluarga nelayan menerapkan pola asuh otoriter, demokratis, dan permisif. Pola asuh otoriter dan demokratis akan membentuk perilaku sosial yang sesuai dengan norma, sedangkan pola asuh permisif akan membentuk perilaku sosial yang tidak sesuai dengan norma.

Pada wilayah yang berbeda, Dewi dan Sunarti (2019) melalukan penelitian tentang persepsi orang tua terhadap pendidikan anak. Hasil penelitian menunjukkan bahwa persepsi orang tua terhadap pendidikan anak tergolong sangat tinggi. Hal ini dapat dilihat dari kemauan, perhatian, dan minat keluarga nelayan di Jorong Pasar Baru Barat pada pendidikan.

Berdasarkan uraian di atas dapat diketahui bahwa kondisi lingkungan khususnya daerah pesisir yang mayoritas berprofesi sebagai nelayan mempengaruhi keinginan untuk memperoleh pendidikan. Akan tetapi, tidak semua orang tua berpandangan bahwa memenuhi kebutuhan ekonomi menjadi prioritas, ada sebagian orang tua yang memperhatikan akan pendidikan sebagai jalan untuk melangsungkan kehidupan.

Melihat kondisi masyarakat nelayan terpencil Tanah Kuning yang masih bersifat tradisional dimana pendidikan Agama Islam belum menyentuh dikarenakan terbatasnya sarana dan prasarana penunjang, seperti tenaga pengajar, ustad-ustad dan da'i. Disamping itu lokasi dan wilayahnya jauh dari jangkuan pemerintah daerah yang semuanya ini sangat berpengaruh dalam pelaksanaan pendidikan Agama Islam. Karakter masyarakat juga lebih cenderung bekerja dari pada menuntut ilmu. Dari keadaan inilah yang sejalan karena tidak ada motivasi dari orang tua untuk menyekolahkan anaknya ke jenjang pendidikan yang lebih tinggi. Sehingga ketika anaknya sudah tamat dari sekolah dasar maka mereka anggap sudah cukup dan setelah lulus anak bisa membantu orang tua bekerja sebagai nelayan yang mampu berpenghasilan. Oleh karena itu dalam mendidik anak tentang pendidikan agama Islam membutuhkan beberapa orang untuk mencetak anak yang bisa lebih baik dan bisa mengerti lebih dalam tentang agama Islam dan Orang tua merupakan pendidik utama dan pertama bagi anak-anaknya kedepan (Derajat, 2011).

Berdasarkan pemaparan tersebut, maka rumusan masalah dalam penelitian ini sebagai berikut: Bagaimana sistem dan praktek pelaksanaan pendidikan agama Islam di Tanah Kuning? Apa saja faktor-faktor yang menjadi pendukung dan penghambat dalam pelaksanaan pendidikan agama Islam, serta Jenis model pendidikan apa yang sesuai 
dengan kondisi masyarakat nelayan Tanah Kuning. Oleh sebab itu, penelitian ini bertujuan untuk 1) Mengetahui karakter masyarakat nelayan terpencil Tanah Kuning, 2) Sistem dan praktek pelaksanaan pendidikan Agama Islam, 3) Faktor pendukung dan penghambat dalam pendidikan Agama Islam, 4) Model pendidikan yang sesuai dengan karakteristik masyarakat nelayan terpencil Tanah Kuning.

\section{METODE}

Penelitian ini menggunakan pendekatan kuantatif yang merupakan prosedur penelitian yang menghasilkan data deskriptif berupa kata-kata tertulis atau lisan dari orang-orang dan pelaku yang dapat diamati (Muslich, 2009). Pelaksanaan pendidikan Agama Islam secara formal pada masyarakat nelayan terpencil Tanah Kuning yaitu penguasan materi, pengusaan alat atau media, dan evaluasi. Variabel dalam penelitian ini yaitu bagaimana karakter masyarakat nelayan terpencil Tanah Kuning, bagaimana perencanaan pemberian pelaksana pendidikan Agama Islam, bagaimana evaluasi yang digunakan oleh pihak sekolah serta apa kendala dalam pendidikan Agama Islam.

\section{Sumber Data}

Jumlah populasi penelitian adalah 224 orang. Adapun yang menjadi sampel siswa sebanyak 59 orang.

Tabel 1. Jumlah Populasi Sampel

\begin{tabular}{cccc}
\hline No & Sekolah & Populasi & Sampel \\
\hline 1. & SD 001 & 51 & 14 \\
2. & SD 002 & 51 & 14 \\
3. & SD 003 & 122 & 31 \\
& Jumlah & 224 & 59 \\
\hline
\end{tabular}

Untuk melengkapi data dari siswa, peneliti mengambil orang tua siswa sebanyak 46 orang dan guru sebanyak 8 orang. Penentuan subyek adalah secara random sampling. Peneliti mengambil secara acak responden yang dibutuhkan dalam penelitian. 


\section{Instrument pengumpulan data}

Pengumpulan data dalam penelitian ini meliputi, 1) Observasi terhadap pelaksanaan kegiatan belajar mengajar pendidikan Agama Islam dalam lima kali setiap kelas. 2) Wawancara melalui beberapa sumber yaitu tiga orang guru pendidikan Islam, orang tua sebanyak lima orang, enam siswa yang terdiri dari tiga siswa dari kelas I, tiga siswa dari kelas II, dan tiga siswa dari kelas III. 3) Dokumentasi berupa data siswa, jumlah guru pendidikan dan sarana yang mendukung pelaksanaan pendidikan Agama Islam. 4) Angket yaitu meminta informasi kepada responden untuk menjawab dengan cara memilih dari pilihan ganda yang telah disediakan. 5) Analisis data dilakukan secara kuantitatif dan kualitatif.

\section{HASIL DAN PEMBAHASAN}

\section{Gambaran umum masyarakat Tanah Kuning}

Masyarakat nelayan terpencil Tanah Kuning mempunyai jumlah penduduk sebanyak 300 Kepala Keluarga dengan 1.272 jiwa. Berikut persentase jumlah penduduk menurut tingkat pendidikan.

Tabel 2. Jumlah Penduduk Menurut Tingkat Pendidikan

\begin{tabular}{llcc}
\hline No & $\begin{array}{c}\text { Tingkat } \\
\text { Pendidikan }\end{array}$ & Frekuensi & $\begin{array}{c}\text { Persentase } \\
(\%)\end{array}$ \\
\hline 1. & Belum & 118 & 9,3 \\
2. & Sekolah & 1018 & 80 \\
3. & SMP & 127 & 10 \\
4. & SMA & 6 & 0,5 \\
5. & D3 & 1 & 0,008 \\
6. & S1 & 2 & 0,12 \\
& Total & $\mathbf{1 . 2 7 2}$ & $\mathbf{1 0 0}$ \\
\hline
\end{tabular}

Tabel 2 menunjukkan bahwa sebagian besar penduduk adalah lulusan SD. Hal ini menunjukkan tingkat pendidikan mereka yang masih minim. 
Tabel 3. Jumlah Penduduk Menurut Jenis Kelamin

\begin{tabular}{cccc}
\hline \multirow{2}{*}{ No } & \multicolumn{2}{c}{ Jenis Kelamin } & Jumlah \\
& Laki - laki & Perempuan & \\
\hline 1. & 60 & 62 & 122 \\
2. & 180 & 125 & 305 \\
3. & 102 & 84 & 186 \\
4. & 88 & 68 & 156 \\
5. & 98 & 64 & 162 \\
6. & 207 & 134 & 341 \\
Total & $\mathbf{7 3 5}$ & $\mathbf{5 5 7}$ & $\mathbf{1 2 7 2}$ \\
\hline
\end{tabular}

Tabel 3 menunjukkan bahwa jumlah penduduk Tanah Kuning adalah laki-laki lebih besar daripada perempuan. Hal ini mendukung mata pencaharian berupa nelayan yang cenderung didominasi laki-laki.

Tabel 4. Jumlah Penduduk Menurut Mata Pencaharian

\begin{tabular}{clcc}
\hline No & $\begin{array}{c}\text { Jenis } \\
\text { Pekerjaan }\end{array}$ & Frekuensi & $\begin{array}{c}\text { Persentase } \\
(\%)\end{array}$ \\
\hline 1. & Nelayan & 142 & 55 \\
2. & Berburu & 40 & 15,5 \\
3. & Pedagang & 39 & 15,1 \\
4. & Penebang & 29 & 11,2 \\
5. Kayu & Lain-lain & 8 & 3,1 \\
& Total & $\mathbf{2 5 8}$ & $\mathbf{1 0 0}$ \\
\hline
\end{tabular}

Tabel 4 di atas memperlihatkan sebagian besar mata pencaharian penduduk adalah nelayan. Hal ini mengingatkan keadaan geografis berupa laut yang meyebabkan mereka cocok bekerja sebagai nelayan. 


\section{Pelaksanaan Pendidikan Agama Islam secara Formal di Sekolah Dasar Masyarakat Nelayan Terpencil Tanah Kuning.}

Pendidikan Agama Islam secara etimologi memiliki tiga istilah, yakni al-tarbiyah, al-ta'lim, dan al-ta'dib. Menurut Al-Shaibani sebagaimana dikutip Tolchah (2015) melihat pendidikan Islam sebagai proses mengubah tingkah laku individu peserta didik pada kehidupan pribadi, masyarakat, dan alam sekitarnya. Proses tersebut dilakukan dengan cara pendidikan dan pengajaran sebagai suatu aktivitas asasi dan profesi.

1. Dasar

Dasar untuk melaksanakan pendidikan Agama Islam adalah Al-Quran dan hadits. Al-Quran itulah yang menjadi landasan penegakan moral tersebut. Keberadaan fungsi Al-Quran sebagai petunjuk bagi manusia dan sebagai sumber ajaran Islam yang pertama, banyak sekali ayat-ayat Al-Quran yang mengandung pelajaran yang bersifat pendidikan dan semuanya itu didasari oleh sumber keilmuan yang paripurna (Rafy. 2009). Ayat-ayat yang menunjukkan perintah untuk melaksanakan pendidikan agama tersebut antara lain: Surat An-Nahl ayat 125, Surat Ali Imran ayat 104, Surat at-Taubah Ayat 122. Pendidikan yang berkualitas tidak lepas dari syarat yang harus dipenuhi. Banyak syarat yang harus dipenuhi oleh para penyelenggara pendidikan jika mereka menginginkan pendidikan bermutu seperti paradigma akademik yang meliputi visi, misi, orientasi, sasaran, tujuan, dan strategi. Pendidikan Agama Islam mempunyai landasan atau dasar yang kuat, baik menurut dasar Agama Islam itu sendiri maupun dasar hukum negara kita. Dasar materi pendidikan agama yang diberikan di Tanah Kuning adalah Alquran dan hadits. Guru mengacu pada kurikulum Departemen Agama.

\section{Evaluasi}

Evaluasi pendidikan karakter adalah rangkain kegiatan yang sistematis dilakukan untuk mengukur, apakah anak sudah memiliki satu atau kelompok karakter yang ditetapkan oleh sekolah dalam kurun waktu tertentu (Kesuma dkk. 2011). Mayoritas siswa berasal dari anak nelayan. Metode mengajar guru meliputi ceramah dan mempergunakan alat peraga. Persepsi siswa menunjukkan apa yang disampaikan guru kadang-kadang membuat siswa mengantuk. Mengenai evaluasi yang dilakukan guru ditunjukkan oleh tabel 5 berikut ini. 


\section{Tabel 5. Keadaan Evaluasi yang dilakukan guru di kelas}

Pernyataan Frekuensi Persentase

(\%)

\begin{tabular}{l|cc} 
Baik & 8 & 13,6 \\
Sedang & 41 & 69,5 \\
Tidak Baik & 10 & 16,9 \\
Total & $\mathbf{5 9}$ & $\mathbf{1 0 0}$
\end{tabular}

Selama ini evaluasi yang sering dilakukan adalah dengan menggunakan evaluasi harian, ujian mid semester dan semester. Hasil belajar siswa ditunjukkan oleh prestasi belajar siswa. Hal ini senada dengan Sutratinah Tirtonegoro (2001) yang menyatakan "prestasi belajar adalah penilaian hasil usaha kegiatan belajar yang dinyatakan dalam bentuk simbol, angka, huruf, maupun kalimat yang dapat mencerminkan hasil yang sudah dicapai oleh setiap anak pada periode tertentu".

Indikator yang dijadikan sebagai tolok ukur dalam menyatakan bahwa suatu prestasi belajar mengajar dapat dikatakan berhasil apabila daya serap terhadap bahan pelajaran yang diajarkan mencapai prestasi tinggi baik secara individu maupun klasikal dan perilaku yang digariskan dalam tujuan instruksional khusus telah dicapai. Berdasarkan tujuan dan ruang lingkupnya tes prestasi belajar dapat dilakukan ke dalam jenis penilaian yaitu:

1. Tes formatif, adalah tes yang dimaksudkan untuk memantau kemajuan belajar peserta didik selama proses belajar berlangsung, untuk memberikan balikan bagi penyempurnaaan program pembelajaran, serta mengetahui kelemahankelemahan yang memerlukan perbaikan.

2. Tes subsumatif, penilaian ini meliputi sejumlah bahan pengajaran atau satuan bahasan yang telah diajarkan dalam waktu tertentu.

3. Tes sumatif, adalah penilaian yang dilakukan jika satuan pengalaman belajar atau seluruh materi pelajaran dianggap telah selesai (Arifin, 2010).

Guru melalui hasil dari tes yang dilakukan dapat mengetahui prestasi baik secara individu maupun kelompok sehingga guru dapat memperbaiki pembelajaran dalam masa yang akan datang. Apabila prestasi siswa rendah, guru dapat meningkatkan pembelajaran yang sesuai dengan karakter siswa. 
Dari hasil observasi dan wawancara yang dilakukan, masyarakat nelayan Tanah Kuning berpendapat bahwa guru agama merupakan orang yang berilmu tinggi dan panutan yang dihormati. Selain itu, gedung sekolah yang sudah layak untuk ditempati dan kondusif dalam kegiatan belajar mengajar merupakan faktor pendukung dalam pelaksanaan pendidikan Islam pada masyarakat terpencil Tanah Kuning. Adapun faktor penghambat adalah kurangnya jumlah guru, kurangnya buku penunjang yang menyebabkan siswa bosan dalam menerima pelajaran, dan tidak ada keberanian dari masyarakat untuk memulai mengubah tradisi membolos sekolah yang menimbulkan persepsi masyarakat yang menganggap pendidikan kurang penting sehingga selalu melibatkan anak untuk membantu orang tua ketika panen tiba.

Metode Pendidikan model Gagne merupakan model Pendidikan yang menciptakan kondisi eksternal yang sejalan dengan kondisi internal proses belajar siswa. Model Pendidikan Agama Islam ini yang sesuai dengan karakteristik masyarakat nelayan Tanah Kuning dan digunakan dalam proses belajar Pendidikan Agama Islam mengingat karakter masyarakat yang tidak bersedia berubah kecuali ada yang memulai.

\section{KESIMPULAN}

Masyarakat nelayan terpencil Tanah Kuning merupakan masyarakat dengan mata pencaharian sebagai nelayan yang mempunyai temperamen keras, namun mereka tidak bersedia membuat perubahan kecuali ada yang memulai. Sistem pendidikan sebagai lembaga formal belum dapat berjalan sesuai dengan tujuan yang ada. Pelaksanaan prestasi belajar menunjukkan siswa mayoritas memiliki prestasi sedang sekitar 41 siswa $(69,5 \%)$, tidak baik sekitar 10 siswa (16,9\%), dan baik sekitar 8 siswa (13,6\%). Faktor pendukung dalam pendidikan Agama Islam dalam masyarakat terpencil Tanah Kuning adalah guru agama yang masih mendapat penghormatan dari masyarakat dan gedung sekolah yang sudah cukup memadai. Faktor penghambatan dalam penelitian ini adalah metode mengajar guru yang monoton menyebabkan siswa bosan, buku penunjang yang kurang memadai, kurangnya jumlah guru yang menyebabkan guru sering kewalahan menghadapi permasalahan dari siswa, dan persepsi masyarakat ataupun orang tua perihal 
pendidikan. Model pendidikan Agama Islam yang sesuai dengan karakteristik masyarakat nelayan Tanah Kuning adalah metode pendidikan model Gagne yang menciptakan kondisi eksternal yang sejalan dengan kondisi internal proses belajar siswa. Sehingga orang tua dan guru sebagai pihak eksternal hendaklah mengingatkan siswa bila harus masuk sekolah.

\section{DAFTAR PUSTAKA}

Arifin, Zainal. 2010. Evaluasi Pembelajaran. Bandung: Remaja Rosdakarya.

Darma Kesuma dkk. 2011. Pendidikan Karakter: Kajian Teori dan Praktik di Sekolah. Bandung: Remaja Rosdakarya.

Derajat, Zakiah. 2011. Ilmu Pendidikan Islam. Jakarta: Bumi Aksara

Dewi, R., \& Sunarti, V. 2019. Persepsi Keluarga Nelayan terhadap Pendidikan Anak. JFACE: Journal of Family, Adult, and Early Childhood Education, 1(2), 209-213. Retrieved from http://ejournal.aksararentakasiar.com/index.php/jface/article/view/30/31

Hamdani, Hamid dan Beni Ahmad Saebani. 2013. Pendidikan Karakter Perspektif Islam. Bandung: Pustaka Setia.

Kementrian Pendidikan dan Kebudayaan RI. 2010. Pengembangan Pendidikan Budaya dan Karakter Bangsa. Jakarta: Kementrian Pendidikan Nasional.

Kusnadi. 2010. Kebudayaan Masyarakat Nelayan. Diambil pada tanggal 20 Januari 2016, darihttp://kebudayaan.kemdikbud.go.id/wpcontent/uploads/sites/37/2014/11 /Buday a_Masyarakat_Nelayan-Kusnadi.pdf.

Masri, Amiruddin. (2017). Pendidikan Anak Nelayan Pesisir Pantai Donggala (The Education For Coastal Fishermen Children In Donggala). Asian Journal of Environment, History and Heritage, 1 (1), 223-227. Retrieved from http://spaj.ukm.my/ajehh/index.php/ajehh/article/view/21

Marlin, Minanti Etika dan Rusdarti. (2016). Konstruksi Sosial Orang Tua Tentang Pendidikan Dan Pola Asuh Anak Keluarga Nelayan. Journal of Educational Social Studies, 5 (2), 150-155. Retrieved from https://journal.unnes.ac.id/sju/index.php/jess/article/view/14080

Muslich, A dan Sri I. 2009. Metodologi Penelitian Kuntitatif. Surabaya: Airlangga University Press.

Rafy, Sapuri. 2009. Psikologi Islam. Jakarta: Rajawali Pers.

Tirtonegoro, Sutratinah. 2001. Anak Super Normal dan Program Pendidikannya. Jakarta: Bina Aksara.

Tolchah, Moch. 2015. Dinamika Pendidikan Islam Pasca Orde Baru. Yogyakarta: LKis Printing Cemerlang. 